\title{
Studies On The Host Defense Enzymes Produced In Rice By Application Of Organic Formulations And Sheath Blight Pathogen Inoculation
}

\author{
Thamarai Selvi, M. ${ }^{1}$, Darwin Christdhas Henry L. ${ }^{2}$, Sutha Raja Kumar ${ }^{3}$, R., Jaiganesh V. ${ }^{4}$, \\ Kannan C. ${ }^{5}$ \\ Department of Plant Pathology, Faculty of Agriculture, \\ Annamalai University, Annamalai Nagar - 608 002, \\ Cuddalore DT, Tamil Nadu. \\ ${ }^{I}$ Corresponding author E-mail: mthamaraiselviprabakaran@gmail.com
}

\begin{abstract}
Organic formulations against rice sheath blight disease are gaining momentum and encompasses all available control methods with each method compensating the deficiencies of other disease management practices. Combined use of biological and seaweed extracts are an important effective against sheath blight disease caused by Rhizoctonia solani .Pot culture experiments were conducted with various organic formulation alone. The different organic formulations (viz., $\mathrm{T}_{1}-$ Pseudomonas fluorescens( $\mathrm{ST}$ ), $\mathrm{T}_{2}$ - Sargassum wightii ( ST) $, \mathrm{T}_{3}=\mathrm{T}_{1}+\mathrm{T}_{2}(\mathrm{ST}), \mathrm{T}_{4}-$ Sargassum wightii ( spray), $\mathrm{T}_{5}=$ Sargassum wightii + Pseudomonas fluorescens ( spray) , $\mathrm{T}_{6}=\mathrm{T}_{3}+\mathrm{T}_{5}, \mathrm{~T}_{7}$ - control) were tested against sheath blight disease incidence and growth and yield attributes in rice under greenhouse condition. Among the treatments, $\left(T_{6}=T_{3}+T_{5}\right)$ recorded the least sheath blight incidence and increase the bio metrics and yield characters. Rice plants treated with $\mathrm{T}_{6}$ followed by challenge inoculation with R. solani gave a maximum induction of $\beta-1,3$-glucanase activity on 5th day after pathogen inoculation and declined thereafter, maximum peroxidase activity at 7 th day after pathogen inoculation then declined slowly, polyphenol oxidase activity on the $7^{\text {th }}$ day and thereafter declined. Maximum activity of phenylalanine ammonia lyase activity was observed on the $7^{\text {th }}$ day of inoculation.
\end{abstract}

Keywords- Sheath Blight, Rice, Enzymatic changes, Peroxidase, Poly Phenol Oxidase, Phenylalanine ammonia lyase

\section{INTRODUCTION}

Rice sheath blight caused by Rhizoctonia solani Kuhn (Teleomorph: Thanatephorus cucumeris (Frank) Donk), is a destructive disease worldwide that causes significant yield loss and quality degradation. Presently, sheath blight disease management is mainly achieved through systemic fungicides. The indiscriminate use of fungicides leads to toxic residues, development of fungicide resistance and environmental pollution. Therefore, under intensive agriculture, there is an urgent need to develop disease control measures alternative to chemicals. Under these circumstances the use of organic formulations becomes the ultimate way of combating this disease. Organic formulations against rice sheath blight are gaining momentum and encompasses all available control methods with each method compensating the deficiencies of others. The present paper investigate the effect of host defense enzymes by application of Bio protectant, sea weed extract and Sheath blight pathogen inoculation.

\section{MATERIALS AND METHODS}

\section{Enzyme Extraction}

The plant tissues collected from plants were immediately homogenized with liquid nitrogen. One gram of powdered sample was extracted with $2 \mathrm{ml}$ of sodium phosphate buffer, $0.1 \mathrm{M}(\mathrm{pH} 7.0)$ at $4 \square \mathrm{C}$. The homogenate was centrifuged for $20 \mathrm{~min}$ at 10,000 rpm. Plighting extract prepared from leaves was used for the estimation of peroxidase (PO), polyphenoloxidase (PPO) and L-phenylalanine ammonia-lyase (PAL).

Peroxidase (PO) (Hammerschmidt et al., 1982)

Peroxidase activity was assayed spectrophotometrically. The reaction mixture consisted of $1.5 \mathrm{ml}$ of $0.05 \mathrm{M}$ pyrogallol, $0.5 \mathrm{ml}$ of enzyme extract and $0.5 \mathrm{ml}$ of 1 per cent $\mathrm{H} 2 \mathrm{O} 2$ which was incubated at room temperature $\left(28 \pm 1^{\circ} \mathrm{C}\right)$. The change in absorbance at $420 \square \mathrm{m}$ was recorded at 30 sec. interval for $3 \mathrm{~min}$ and the boiled enzyme preparation served as blank. The enzyme activity wasexpressed as change in the absorbance of the reaction mixture min-1 g-1 on fresh weight basis. Polyphenoloxidase (PPO) (Mayer et al., 1965)

The reaction mixture consisted of $1.5 \mathrm{ml}$ of $0.1 \mathrm{M}$ sodium phosphate buffer (pH 6.5) and $200 \square 1$ of the enzyme extract. To start the reaction, $200 \square 1$ of 0.01 $\mathrm{M}$ catechol was added and the activity was expressed as changes in absorbance at $495 \mu \mathrm{m}$ min- $1 \mathrm{~g}-1$ fresh weight of tissue.

Phenylalanine Ammonia-Lyase (PAL) (Ross and Sederoff, 1992)

The assay mixture containing $100 \mu 1$ of enzyme, 500 $\mu 1$ of $50 \mathrm{~mm}$ Tris $\mathrm{HCl}(\mathrm{pH} \mathrm{8.8)}$ and $600 \mu 1$ of 1mMLphenylalanine was incubated for $60 \mathrm{~min}$. The reaction was arrested by adding $2 \mathrm{~N} \mathrm{HCl}$. Later, $1.5 \mathrm{ml}$ of toluene was added and vortexed for $30 \mathrm{sec}$. The centrifuged (1000 rpm, $5 \mathrm{~min})$ toluene fraction 
International Journal of Research in Advent Technology, Vol.7, No.4, April 2019

E-ISSN: 2321-9637

\section{Available online at www.ijrat.org}

containing trans-cinnamic acid was separated. The toluene phase was measured at $290 \square \mathrm{m}$ against the blank of toluene. Standard curve was drawn with graded amounts of cinnamic acid in toluene as described earlier. The enzyme activity was expressed as $\square$ moles of cinnamic acidmin- $1 \mathrm{~g}$ fresh tissue- 1 .

$\square$-1, 3-glucanase (Pan et al., 1991)

Crude enzyme extract of $62.5 \mu \mathrm{l}$ was added to $62.5 \mu \mathrm{l}$ of 4 per cent laminar in and incubated at $40 * \mathrm{C}$ for 10 min. The reaction was stopped by adding $375 \mu 1$ of dinitrosalicylic acid (DNS) and heated for $5 \mathrm{~min}$ on boiling water bath (DNS prepared by adding $300 \mathrm{ml}$ of 4.5 per cent $\mathrm{NaOH}$ to $880 \mathrm{ml}$ containing $8.8 \mathrm{~g}$ of DNS and $22.5 \mathrm{~g}$ potassium sodium tartarate). The resulting colored solutions were diluted with distilled water, vortexed and the absorbance was read at $500 \mu \mathrm{m}$. The crude extract preparation mixed with laminar in at zero time incubation served as blank. The enzyme activity was expressed as *g equivalents of glucose min-1 $\mathrm{g}$ fresh weight-1.

Compatibility Of Seaweeds With P. Fluorescens (Utpal Dey et al., 2015)

The compatibility was determined for P. fluorescens, seaweed extract, by using PDA and KB medium, respectively. The medium was mixed with the $\mathrm{P}$. fluorescens each at $2 \mathrm{ml} / 18 \mathrm{ml}$ of PDA. Each milliliter of fungal and bacterial suspension contained $1 \times 108$ $\mathrm{cfu} / \mathrm{ml}$. the medium containing biocontrol agents were poured into Petri plates and immediately after solidification, two sterile paper discs were placed at equidistance to each other on the seeded medium. $5 \mathrm{ml}$ of the 20 per cent seaweed extract after passing through bacterial filters was added to first sterile filter paper disc and $5 \mathrm{ml}$ of $0.01 \mathrm{ml}$ of sterile distilled water was added to second filter paper disc as control, respectively. The plates were incubated at room temperature $72 \mathrm{~h}$ (P. fluorescens) and observed for the inhibition zone. Absence of inhibition zone around the disc indicates the compatibility with respective bacterial and fungal isolates and the presence of inhibition zone indicates the incompatibility.

\section{INDUCTION OF DEFENSE ENZYMES}

Green house study was conducted to test the induction of defense enzyme on rice plants with different application of organic formulation.

\section{$\beta$-1, 3-glucanase}

$\beta$-1,3-glucanase activity was observed in the leaf samples of rice at different day intervals. Among the various's treatment, the plants treated with S. wightii ,P. fluorescens (seed treatment, prophylactic spraying at 15, 30 and 45DAT) and followed by challenge inoculated with $R$. solani $\left(\mathrm{T}_{6}\right)$ recorded a maximum induction of $\beta$-1,3-glucanase activity 250.8 $\mu \mathrm{g}$ of Glucose released/ $\mathrm{min} / \mathrm{g}$ of fresh tissue on 5 th day after pathogen inoculation. It was followed by the plants treated with application of S. wightii ( prophylactic spray at 15,30 and $45 \mathrm{DAT})\left(\mathrm{T}_{5}\right)$ recorded $240.5 \mu \mathrm{g}$ of Glucose released/ $\mathrm{min} / \mathrm{g}$ of fresh tissue on 5 th day after pathogen inoculation.
The enzyme activity significantly increased up to 5th day from the pathogen inoculation and then declined slowly in all the treatments ( Fig 1).

\section{Peroxidase (PO)}

The activity of PO was observed in leaf sample of rice at different days interval. Among the various treatment, the plants treated with $S$. wightii, $P$. fluorescens, (seed treatment, prophylactic spraying at 15, 30, and 45 DAT) and followed by challenge inoculated with $R$. solani $\left(\mathrm{T}_{6}\right)$ recorded maximum induction of Peroxidase activity (62.50 changes in absorbance/min/g of fresh tissue) at $7^{\text {th }}$ day after pathogen inoculation. It was followed by the plants treated with $S$. wightii ( prophylactic spray at 15 and 30.45 DAT) $\left(\mathrm{T}_{5}\right)$ recorded a maximum induction of (59.96 changes in absorbance/ $\mathrm{min} / \mathrm{g}$ of fresh tissue) respectively at the $7^{\text {th }}$ day after pathogen inoculation. The enzyme activity significantly increased up to $7^{\text {th }}$ day from the pathogen inoculation and then declined slowly in all the treatments ( Fig 2).

\section{Polyphenoloxidase (PPO)}

Application of $S$. wightii, $P$. fluorescens(seed treatment, prophylactic spraying at 15,30 , and 45 DAT) and followed by challenge inoculated with $R$. solani $\left(\mathrm{T}_{6}\right)$ recorded maximum induction of PPO activity (3.38 changes in absorbance/min/g of fresh tissue) at $7^{\text {th }}$ day, which decreased further. Without inoculation of pathogen and organic combination, a minimum poly phenol activity was recorded when compared to all other treatments. In all the treatments, enzyme activity increased up to $7^{\text {th }}$ day and there after declined ( Fig 3 ).

\section{Phenylalanine Ammonialyase (PAL)}

PAL activity was found to increase significantly in plants treated with $P$. fluorescens, $S$. wightii (seed treatment, prophylactic spraying at 15, 30 and 45 DAT) inoculated with R.solani $\left(\mathrm{T}_{6}\right)$. Maximum induction of PAL activity ( 5.10 changes in absorbance $/ \mathrm{min} / \mathrm{g}$ of fresh tissue) at $7^{\text {th }}$ day. There after it decreased. It was followed by the application of $S$. wightii (prophylactic spray at 15, 30and 45 DAT) $\left(\mathrm{T}_{5}\right)$ recorded a maximum induction at the $7^{\text {th }}$ day of (5.03 changes in absorbance $/ \mathrm{min} / \mathrm{g}$ of fresh tissue) respectively. The enzyme activity significantly increased up to $7^{\text {th }}$ day from the pathogen inoculation and then declined slowly in all the treatments ( Fig 4 ). tissue on 5th day after pathogen inoculation.

\section{DISCUSSION:}

Sheath blight of rice caused by Rhizoctonia solani is one of the most important fungal diseases affecting rice plant and assuming greater importance all over the rice growing areas. In India, Yield losses due to sheath blight infection ranges from 8 to $50 \%$ depending on severity of the disease, stage of the crop at which it was infected by the fungus and overall environmental conditions (Savaryet al., 2000; Singh et al., 2004). Hence this study is carried out to assess the yield loss due to infection and formulate the effective scope of organic formulation management practices. 
International Journal of Research in Advent Technology, Vol.7, No.4, April 2019

E-ISSN: 2321-9637

\section{Available online at www.ijrat.org}

\section{Induction Of Defense Mechanism}

Plants are bestowed with various defense related genes and it is well known that the defense genes are sleeping genes and appropriate stimuli or signals are needed to activate them. Inducing the plants own defense mechanisms by prior application of biological inducer is thought to be a novel plant protection strategy. Inductions of systemic resistance by marine products and organic amendments have been reported earlier by several workers (Poonpolgul and Kumphai, 2007; Jayaraj et al., 2008; Ngullieet al., 2010; Flora and Maria Victorialrani, 2012).

In the present study, rice plants pretreated with $S$.wightii, P. fluorescens, (seed treatment + prophylactic spraying at 15,30 and $45 \mathrm{DAT})\left(\mathrm{T}_{6}\right)$ significantly induced the synthesis and accumulation of $\beta$-1,3-glucanase, PO, PPO and PAL, against $R$. Solaniwhen compared to all the other treatments.

The enzyme activity significantly increased from $7^{\text {th }}$ day after the pathogen inoculation and then declined in all the treatments. Similar results were shown by Jayarajet al. (2008), who reported that, Ascophyllumnodosum + chlorothalonil treatment recorded a maximum induction of PO, PPO, PAL, $\beta-1,3-$ glucanase, and total phenols than the application of $A$. nodosumalone in carrot against Alternaria leaf spot disease.

One application of extract at 0.8 or $1.61 \mathrm{ha}^{-1}$ stimulated PO activity and two applications caused an eight-fold increase in PO activity. The treated leaves accumulated highest capsidiol (a phytoalexin in peppers) concentrations when compared to the control (Lizziet al., 1998). Incorporation of A. nodosum extract into the planting medium caused a delayed and reduced incidence of Verticillium wilt of pepper plants. These plants also contained higher levels and early accumulation of phenolics (Garcia-Mina et al., 2004).

Activity of certain defense - related enzymes, including peroxidase, polyphenyloxidase, phenylalanine ammonia- lyase, chitinase and $\beta$ - 1,3glucanase were significantly increased in plants treated with seaweed (Jayarajet al., 2008, Manoj Kumar Solankiet al., 2012) this is in accordance with our present findings.

Increase in PO and PPO activity at a later stage may contribute to cross linking of hydroxyproline rich glycoproteins (HRGPs), lignifications that will act as barriers against pathogen entry. POgenerated hydrogen peroxide may function as an antifungal agent in disease resistance. Hydrogen peroxide inhibits pathogens directly or it may generate other free radicals that are antimicrobial in nature (Chen et al., 2000). PO is a key enzyme in the biosynthesis of lignin and other oxidised phenols (Bruce and West, 1989). PAL plays an important role in the biosynthesis of phenolics and phytoalexins(Daayfet al., 1997). The increase in PAL activity indicates the activation of the phenyl proponed pathway. The product of PAL is transcinnamic acid, which is an immediate precursor for the biosynthesis of salicylic acid; a signal molecule in systemic acquired resistance (SAR) (Klessigand Malamy, 1994). PAL is a key enzyme of phenylpropanoid metabolism which leads to the synthesis of phenols (Massalaet al., 1980). These enzymes act upon the fungal cell wall resulting in degradation and loss of inner contents of cells (Benhamou et al., 1996). The enzymatic degradation of the fungal cell wall may release non-specific elicitors (Hammerschmidt et al., 1982) which in turn elicits various defense reactions. The fungal cell wall elicitors have been reported to elicit various defense reactions in green gram (Ramanathanet al., 2000). The phenomenon of $h$ free-proline accumulation in plants exposed to diverse environmental and biological stresses have considerable physiological significance.

In conclusion, prior treatment of combined application of $S$ wightii, $P$. fluorescens (seed treatment + prophylactic spraying at 15,30 and 45 DAT) $\left(\mathrm{T}_{6}\right)$ followed by challenge inoculation with $R$. solani triggered the plant mediated defense mechanism that in turn reduce the sheath blight incidence in rice.

\section{REFERENCES}

[1] Chen C, Belanger RR, Benhamou N and Paulitz T (2000).Defense enzymes induced in cucumber roots by treatment with plant growth promoting rhizobacteria (PGPR) and Pythium aphanidermatum. Physiology and Molecular Plant Pathology. 56: 13-23.

[2] Daayf F, Bel-Rhlid R and Belanger RR (1997). Methyl ester of p-coumaric acid: A phytoalexinlike compound from long English cucumber leaves. Journal of Chemical Ecology. 23: 15171526

[3] Flora G and Maria Victoria Rani S (2012). An approach towards control of blast by foliar application of seaweed concentrates. Science Research Reporter2: 213-217. Food Microbiology. 103: 305-314

[4] Garcia-Mina JM, Goicoechea N, Aguirreolea J (2004). Alleviation of Verticillium wilt in pepper (Capsicum annuum L) by using the organic amendment COAH of natural origin. Sci. Hortic.101: 23-37.

[5] Hammerschmidt R, Nuckles EM and Kuc J (1982). Association of enhanced peroxidase activity with induced systemic resistance of cucumber to Colletotrichum lagenarium. Physiological Plant Pathology. 20: 73-80

[6] Jayaraj J, Wan A, Rahman M and Punja ZK (2008). Seaweed extract reduces foliar fungal disease on carrot. Crop Protection. 27: 1360-1366

[7] Klessig DK and Malamy J (1994).The salicylic acid signal in plants. Plant Molecular Biology. 26: 1439-1458.

[8] Lizzi Y,Coulomb C, Polian C, Coulomb PJ, and Coulomb PO (1998). Seaweed and mildew: 


\section{Available online at $w w w . i j r a t . o r g$}

Laboratory tests have produced encouraging results. Phytoma.508:29-30 .

[9] Manoj Kumar Solanki, Sudheer Kumar, Akhilesh Kumar Pandey, SupriyaSrivastava, Rajesh Kumar Singh, Prem L. Kashyap, Alok K. Srivastava Dilip, K and Arora (2012). Diversity and antagonistic potential of Bacillus spp. associated to the rhizosphere of tomato for the management of Rhizoctonia solani, Biocontrol Science and Technology. 22: 203-217.

[10] Massala R, Legrand M and Fritig B (1980).Effect of $\square$-amino-oxyacetate, a competitive inhibitor of phenylalanine ammonia lysae, on the hypersensitive resistance of tobacco to tobacco mosaic virus. Physiol. Plant Pathol.16: 213-226.

[11] Mayer AM, Harel E and ShaulRb (1965). Assay of catecholoxidase, critical comparison of methods. Phytochemistry.5: 783-789

[12]N gullie M , DAIHO L, upadhayay (2010). Biological management of fruit rot in the world's hottest chilli (Capsicum Chinese jacq ). Journal of plant protection research.50: 269-273 .

[13] Pan S, Ye Q and Kuc J (1991).Association of 1,3 glucanase activity and isoform pattern with systemic resistance to blue mold in tobacco induced by stem injection with Perenospora tabacina (or) leaf inoculation with tobacco mosaic virus. Physio .Mol.PL.Pathol.39:25-39

[14] Poonpolgul S and Kumphai S (2007). Chili pepper anthracnose in Thail and. First international symposium on chili anthracnose. Jrnl of Zhejiang UnivSci B. 23:17-19.

[15] Ramanathan A, Samiyappan R and Vidhyasekaran P (2000). Induction of defense mechanisms in greengram leaves and suspensioncultured cells by Macrophomina phaseolina and its elicitors. Journal of Plant Diseases and Protection.107: 245-257.

[16]Ross WW and Sederoff RR (1992). Phenylalanine ammonia lyase from loblolly pine: purification of the enzyme and isolation of complementary DNA clone. Plant Physiol. 98: 380-386.

[17] Savary S, Willocquet L, Elazegui FA, Castilla N, Teng, PS (2000). Rice pest constraints in tropical Asia; quantification and yield loss due to rice pests in a range of production situations. Plant diseases. 84: 357-369.

[18] Singh N, Sarvmittar and Sandhu KS (2004). Incidence and losses caused by sheath blight of paddy in Punjab. Plant Disease Research.19: 91 (Abstract).

[19] UtpalDey, Harlapur SL , Dhutraj DN, Suryawanshi AP, Ritika Bhattacharje (2015). Integrated disease management strategy of common rust of maize incited by Puccinia sorghi Schw. African Journal of Microbiology Research. pp 9: 1345-1351. 
International Journal of Research in Advent Technology, Vol.7, No.4, April 2019 E-ISSN: 2321-9637

Available online at www.ijrat.org

Figure 1. $\beta$-1,3-glucanase activity ${ }^{\sigma}$ in rice plants treated with different organic formulations under green house condition

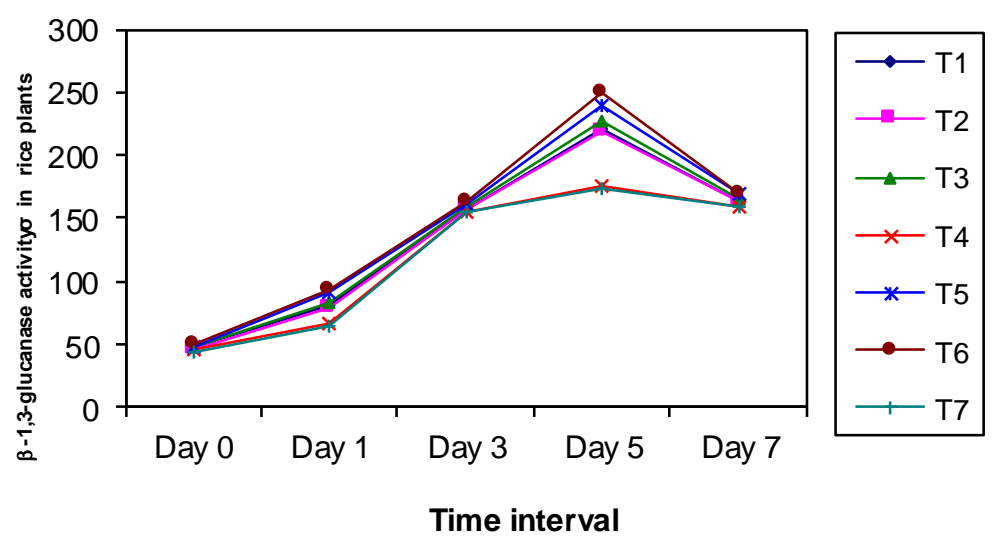

Figure 2. Peroxidase activity ${ }^{\sigma}$ in rice plants treated with different organic formulations under green house condition

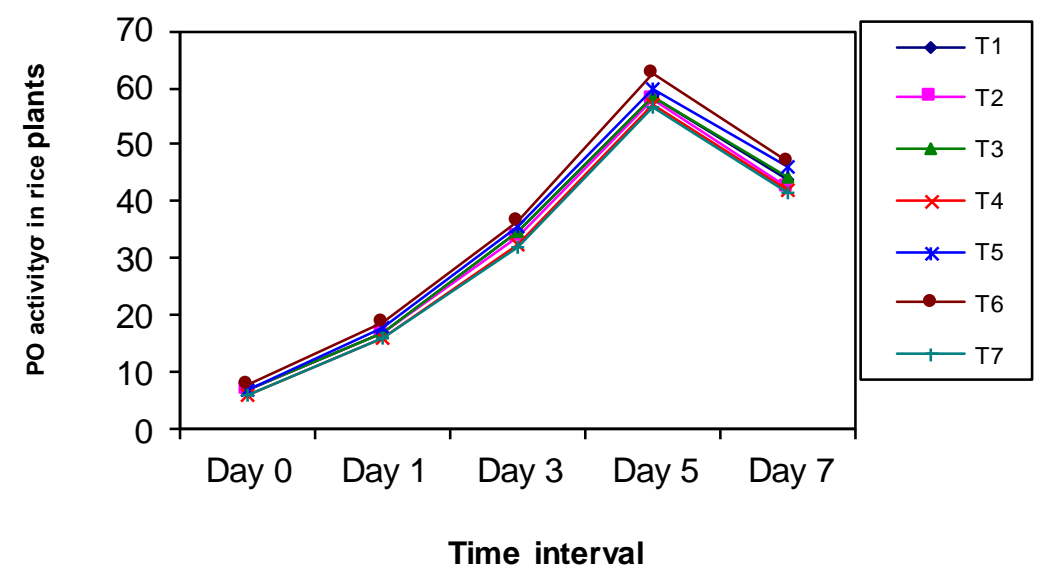


International Journal of Research in Advent Technology, Vol.7, No.4, April 2019 E-ISSN: 2321-9637

Available online at www.ijrat.org

Figure 3. polyphenoloxidase activity ${ }^{\sigma}$ in rice plants treated with different organic formulations under green house condition

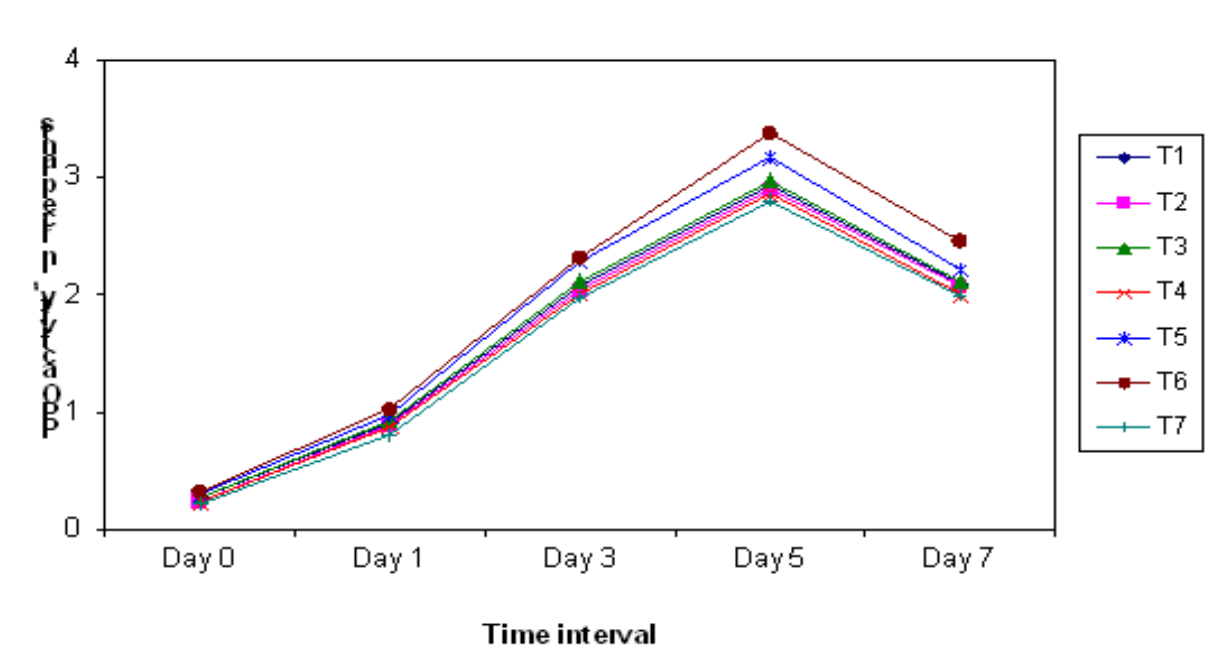

Figure 4. Phenylalanine ammonia-lyase activity ${ }^{\sigma}$ in rice plants treated with different organic formulations under green house condition

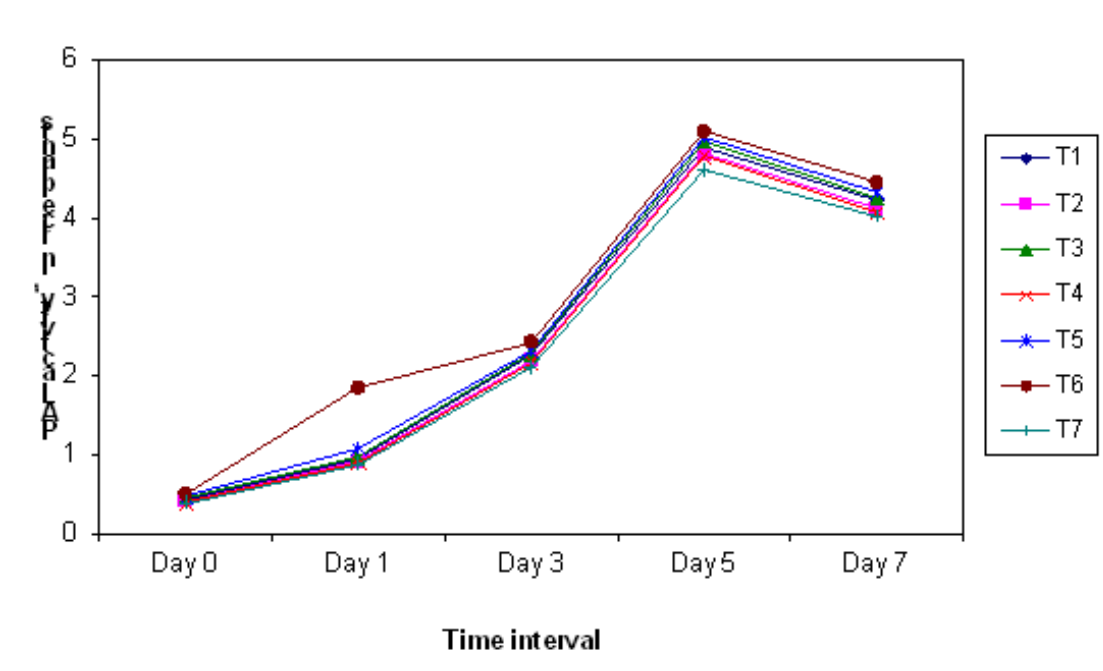

